\title{
Impact of Nationalist Sentiments and Commitment for Prioritising the ASEAN Economic Community: Empirical Analysis from Survey in Indonesia, Malaysia and Singapore
}

\author{
Guido Benny \\ Ravichandran Moorthy \\ Sity Daud \\ Zarina Othman \\ School of History, Politics and Strategy, Universiti Kebangsaan Malaysia, \\ 43600 UKM Bangi, Selangor Darul Ehsan, Malaysia \\ Email: guidobenny@gmail.com
}

Doi:10.5901/mjss.2015.v6n1s1p188

\begin{abstract}
This study examines how nationalist sentiments affect the public's commitment to prioritize the proposed ASEAN Economic Community and its three features - free flow of goods and services, free movement of skilled/professional workers and freedom to invest in the region. It analyzes statistical data from public opinion surveys conducted to 1,040 respondents from eleven cities in Indonesia, Malaysia and Singapore in 2010. Tested by OLS regression analysis, the study finds some mixed findings for the four hypotheses, differences in results in the three ASEAN countries, and issues specific to developing countries that vary the results from the European integration.
\end{abstract}

Keywords: Nationalist sentiments, Commitment for regional integration, ASEAN Economic Community, Economic regionalism

\section{Introduction}

ASEAN leaders have announced the ASEAN Vision 2020 in December 1997 that envisaged "a stable, prosperous and highly competitive ASEAN Economic Region in which there is a free flow of goods, services and investments, a freer flow of capital, equitable economic development and reduced poverty and socio-economic disparities" by the year 2020 (ASEAN Secretariat, 1997). Subsequently, the founding document of ASEAN Community - the Declaration of Bali Concord II - in 2003 announced the ASEAN Economic Community (AEC) as its new goal for economic integration (ASEAN Secretariat, 2003). The lofty goals of the AEC were translated into action when the Declaration on the AEC Blueprint was issued in 2007. The Blueprint is essentially a master plan formulated for guiding the achievement of an AEC by 2015 by means of detailing economic integration measures, commitment, targets and timelines for their implementation into four pillars, namely, a single market and production base, a competitive economic region, equitable economic development and full integration into the global economy (ASEAN Secretariat, 2009).

It is arguable that realising AEC requires a bottom up approach as a community cannot be built without engaging interests of the public (Benny, Rashila and Tham, 2014; Das, 2012; Tham, 2008). Public opinion of the people living in a region can affect the outcomes of regional integration in subtle ways as negative perceptions can lead to a general lack of support for economic integration as has been the case in the South Asian countries (Kher, 2012). However, there is a notable absence of studies capturing public voices on an AEC. Studies on ASEAN are numerous, yet they were conducted using the elite decision making approach for assessing the establishment processes or the social, political, and economic challenges of ASEAN (Acharya 2003; Guerrero 2008; Hew 2007;) as well as the readiness of the business sector for AEC (Abidin, Loh and Aziz 2012; Mugijayani and Kartika 2012). Studies involving public opinion in ASEAN are quite rare - only a few studies so far exist conducted by Benny, Rashila and Tham (2014); Abdullah and Benny (2013), Abdullah, Benny and Din (2010), Benny and Abdullah (2011), Moorthy and Benny (2012a, 2012b, and 2013); and Thompson and Thianthai (2008), but none of those studies discusses about the role of nationalist sentiments in influencing public commitment for the AEC.

The objective of this paper is to discuss how nationalist sentiments affect the public's commitment to prioritize the proposed ASEAN Economic Community and its three features - free flow of goods and services, free movement of 
skilled/professional workers and freedom to invest in the region. It argues that public economic nationalist sentiments should be taken into consideration in the policies for establishing regional integration in developing countries because they may affect the public commitment to regional economic integration. The result of this paper will benefit policy makers of ASEAN economic integration. Academically, this paper will add knowledge to regionalism studies, international politics, and international political economics on the role of nationalism sentiments on attitudes towards regional economic integration.

\section{Studies on Nationalist Sentiments and Attitude towards Regional Economic Integration}

Previous researches have not systematically examined how nationalist sentiment relates with commitments to prioritise economic regional integration. Despite many scholarly discussions about economic nationalism and attitudes towards economic regional integration, the relationship between nationalist sentiments and public commitment for regional integration has not been clearly elucidated.

Literature on social identity reveals two findings regarding relationships between national identity and attitudes towards regional integration. Some scholars find the possibility of individual showing strong national attachments while simultaneously supporting the European integration project and suggest that, since social identities are multi-layered and flexible rather than singular and rigid, some individuals can adopt a regional identity simultaneously with their national identity (Dowley \& Silver, 2011; Hooghe and Marks, 2004; Smith, 1993). On the other hand, most studies under the social identity approach argue that national identity may go against regional integration and contend that individuals who have strong attachments to their national identity might perceive the unification of member states as a threat to national identity because it blurs the distinctions between national communities (Christin \& Trechsel, 2002; Hooghe \& Marks, 2005; McLaren, 2007; Shore, 1993; Smith, 1992).

Various empirical public opinion studies demonstrate the negative association between national attachment and support for regional initiatives. Christin and Trechsel (2002) find that the stronger the national attachment and national pride of Swiss citizens, the less likely they are to support membership in the EU. Hooghe and Marks (2004) find that strength of national identity is a better predictor of attitudes toward the EU than utilitarian variables. Hooghe and Marks (2005) exhibit that individuals who conceptualize their identities in exclusively national (rather than civic) terms are the most hostile to European integration. Furthermore, analysis of waves of Eurobarometer surveys and the ISSP National Identity surveys seem to confirm that Europeans are still primarily attached to their national identity first than to the European identity (Duchesne and Frognier 1995).

\section{Hypothesis}

While choosing goods, workers or investment, it is hypothesised that individuals will be friendlier to those from intraregion than outside the region. Thus, the hypotheses of the study are as follow:

$H:$ Individuals who show higher nationalist sentiments will exhibit lower commitment to:

$H_{1}$ : prioritise $A E C$,

$\mathrm{H}_{2}$ : prioritise buying goods from ASEAN countries than those from countries outside ASEAN.

H3: prioritise giving opportunities to skilled/professional workers from ASEAN countries than those from countries outside ASEAN.

$H_{4}$ : prioritise investment from ASEAN countries than those from countries outside ASEAN.

\section{Method}

\subsection{Measures, Sample and Survey Procedures}

The study uses primary data of a survey conducted by authors in three ASEAN countries - Indonesia, Malaysia and Singapore. The use of quantitative survey methods is scientifically reasonable as most studies on ASEAN regionalism utilise qualitative observation methods. In this case, the use of quantitative survey will provide original empirical insight to the field of ASEAN studies because of the inexistence of public opinion survey pertaining to the issues under study.

The survey was aimed to collect information on public commitment for the AEC and nationalist sentiments in three countries. The selection of the three countries were justified as: (1) these countries are among the five founder countries of ASEAN; (2) they are considered important in ASEAN terms of territorial size, population, and economy; and (3) these countries maintain closed cooperation among them but there are some problems persist in the relationships among 
countries and between citizens or people. In these three countries, interviewers travelled to lead the survey process in five cities in Indonesia (Jakarta, Medan, Makassar, Pontianak and Surabaya), five cities of Malaysia (Johor Bahru, Kota Kinabalu, Kuala Lumpur, Melaka, and Penang), and three areas in Singapore (National University of Singapore, Nanyang Technological University and Singapore city centre). The cities were purposively chosen in terms of their significance to economy, polity, and socio-culture of the countries and their connectedness to other countries in the region (Moorthy and Benny, 2012a: 1047).

Due to differences in languages used in the three countries, questionnaires were made available in three languages (Bahasa Indonesia, Bahasa Malaysia, and English). The questionnaires were checked carefully by the professional editors in three languages to ensure that the original ideas of the questions were not diluted. The questionnaires were screened in pre-tests, involving 30 respondents for each type of questionnaires, to check the structure of the questions and the understanding of target respondents.

The survey conducted involved 1,040 respondents - 426 Indonesians, 401 Malaysians, and 213 Singaporeans between June and December 2009 (Table 1). The respondents were selected using convenience quota sampling, balancing the proportion of university students with nonstudent respondents with tertiary education. The reason for this qualification is the nature of the survey questions, which requires respondents with tertiary education to respond appropriately.

Profiles of the respondents are as follow. Those surveyed consisted of $50.8 \%$ male and $49.2 \%$ female respondents. The majority of them are younger mature (75.4\%), single (70.7\%), with undergraduate education background (72.4\%) and lower to middle level of household expenditure. Students (46.2\%), lecturers (21.9\%), and private-sector employees (15.1\%) were the three major occupations of respondents. (See Table 1).

Table 1: Profile of Respondents

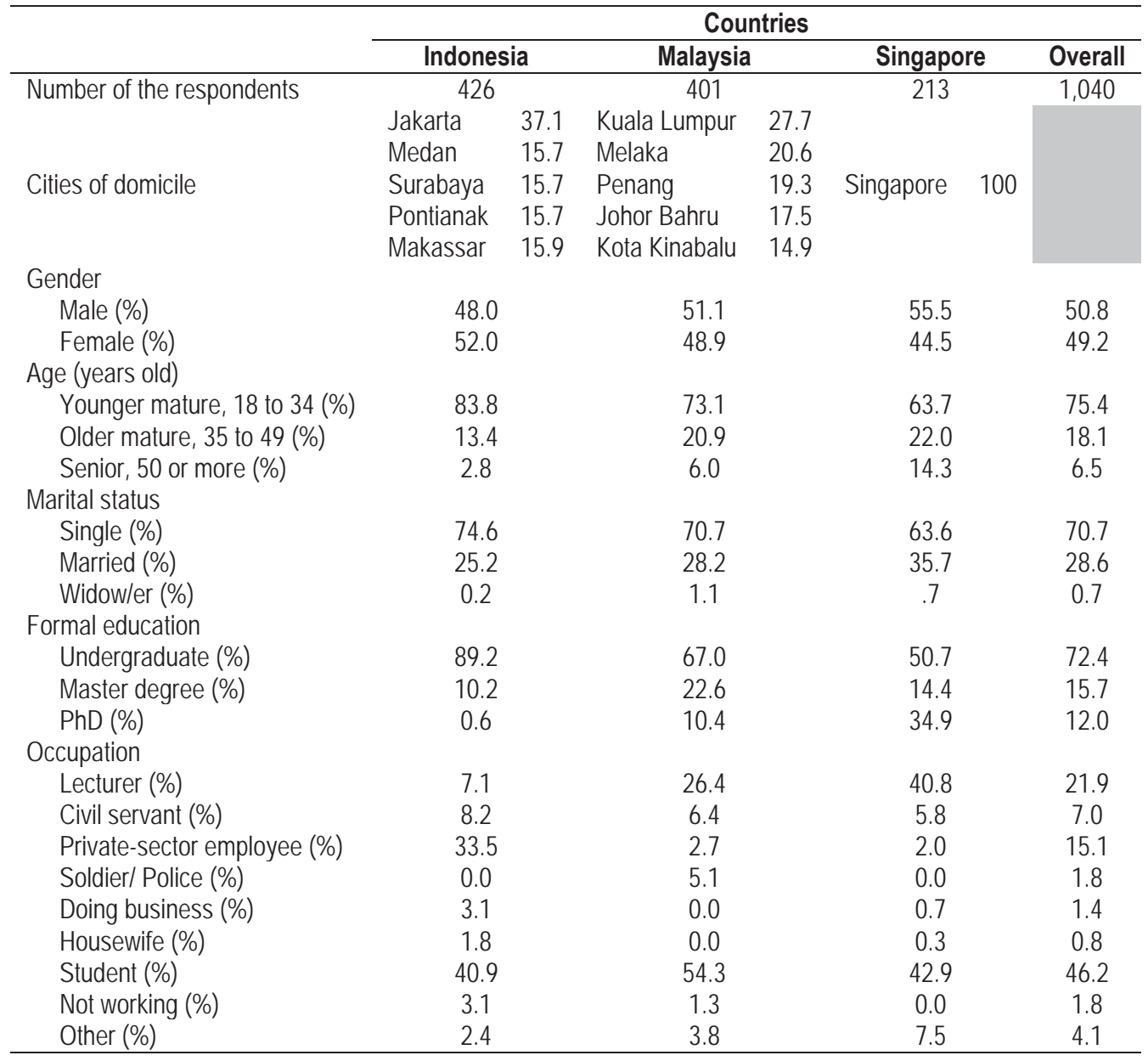




\subsection{Measuring Dependent Variables}

Regional economic integration is usually defined as the removal or reduction of barriers to trade in goods and services and to movement of labour and capital across borders (Kwon, 2010: 5). Thus, the dependent variables for the present study are commitment to prioritise the AEC, goods from ASEAN, investment from intra-ASEAN and skilled professional workers as the those are the three features of the AEC (free flows of goods and services, free movement of skilled/professional ASEAN workers, and the freedom for ASEAN businesspeople to establish companies anywhere in the region). Because it is assumed that not all respondents know the concept of $A E C$, a brief description of the concept of the ASEAN economic integration was conveyed as follow:

"The ASEAN Economic Community is the one of the pillars of the ASEAN Community. The end-goal, as outlined in the ASEAN Vision 2020, is the total economic integration of the region. They are to create a stable, prosperous and highly competitive ASEAN economic region in which there are free flows of goods, services, investments and freer flows of capital, equitable economic development and reduced poverty and socio-economic disparities in year 2020."

After the brief description of AEC, the questionnaires forwarded the instruction for circling the most appropriate number of the level of respondent' agreement for each statement, followed by three statements measuring their commitment for the AEC. The complete description of the questions together with their validity and realibility are presented at the Table 2 while the descriptive statistics of this variable are conveyed in Table 3.

Table 2: Survey questions wording, validity and reliability of variable

\begin{tabular}{|c|c|c|c|}
\hline & $\begin{array}{l}\text { Anti-image } \\
\text { matrix }\end{array}$ & $\begin{array}{l}\text { Component matrix's } \\
\text { factor loading }\end{array}$ & $\begin{array}{l}\text { KMO Measure of Sampling } \\
\text { Adequacy, }\end{array}$ \\
\hline \multicolumn{4}{|l|}{ Dependent Variable: Commitment to Prioritise AEC } \\
\hline $\begin{array}{l}\text { 1. "When buying goods, we should give priority to goods from ASEAN rather than } \\
\text { Non-ASEAN's" (1) Strongly disagree; (2) Disagree; (3) Uncertain; (4) Agree; (5) } \\
\text { Strongly agree. }\end{array}$ & 0.76 & 0.77 & \multirow{3}{*}{$\begin{array}{l}\text { - } \text { KMO-MSA = } 0.73 \\
\text { - } \text { Bartlett's Test's Approx. } \\
\text { - } \text { chi-square = 1658.87; sig = } \\
0.00 \\
\text { - } \text { Total variance explained = } \\
\text { - } 79.01 \% \\
\text { - } \text { Chronbach's Alpha }=0.87\end{array}$} \\
\hline $\begin{array}{l}\text { 2. "Priority should be given to investment and investors from ASEAN countries } \\
\text { than to those from countries outside ASEAN" (1) Strongly disagree; (2) Disagree; } \\
\text { (3) Uncertain; (4) Agree; (5) Strongly agree. }\end{array}$ & 0.69 & 0.83 & \\
\hline $\begin{array}{l}\text { 3. "Priority should be given to skilled/professional workers from ASEAN countries } \\
\text { than those from countries outside ASEAN" (1) Strongly disagree; (2) Disagree; (3) } \\
\text { Uncertain; (4) Agree; (5) Strongly agree. }\end{array}$ & 0.75 & 0.77 & \\
\hline \multicolumn{4}{|l|}{ Independent Variable 1: Political Nationalist Sentiments } \\
\hline $\begin{array}{l}\text { 1. "Patriotism should be one of the main objectives of education, so our children } \\
\text { believe that our country is one of the best in the world" (1) Strongly disagree; (2) } \\
\text { Disagree; (3) Uncertain; (4) Agree; (5) Strongly agree. }\end{array}$ & 0.69 & 0.72 & \multirow{3}{*}{$\begin{array}{l}\text { - } \text { KMO-MSA = } 0.64 \\
\text { - } \text { Bartlett's Test's Approx. } \\
\text { - } \text { chi-square = 424.60; sig = } \\
0.00 \\
\text { - } \text { Total variance explained = } \\
\text { - } 58.03 \% \\
\text { - } \text { Chronbach's Alpha = } 0.62\end{array}$} \\
\hline $\begin{array}{l}\text { 2. "I will protest if the leader of a foreign country undermines the pride of my } \\
\text { nation and country" (1) Strongly disagree; (2) Disagree; (3) Uncertain; (4) Agree; } \\
\text { (5) Strongly agree. }\end{array}$ & 0.63 & 0.78 & \\
\hline $\begin{array}{l}\text { 3. "I will be really angry if there is/are foreign country(ies) claiming the territory of } \\
\text { my country" (1) Strongly disagree; (2) Disagree; (3) Uncertain; (4) Agree; (5) } \\
\text { Strongly agree. }\end{array}$ & 0.62 & 0.79 & \\
\hline \multicolumn{4}{|l|}{ Independent Variable 2: Socio-cultural Nationalist Sentiments } \\
\hline $\begin{array}{l}\text { 1. "I am always proud of the beauty of my country" (1) Strongly disagree; (2) } \\
\text { Disagree; (3) Uncertain; (4) Agree; (5) Strongly agree. }\end{array}$ & 0.79 & 0.83 & \multirow{4}{*}{$\begin{array}{l}\text { - } \text { KMO-MSA = } 0.78 \\
\text { - Bartlett's Test's Approx. } \\
\text { chi-square = 1484.70; sig = } \\
\text { 0.00 } \\
\text { - } \text { Total variance explained = } \\
64.05 \% \\
\text { - } \text { Chronbach's Alpha = } 0.80\end{array}$} \\
\hline $\begin{array}{l}\text { 2. "I am very proud of the history and cultural heritage of my country as it forms } \\
\text { the roots of history and culture for the Southeast Asian region" (1) Strongly } \\
\text { disagree; (2) Disagree; (3) Uncertain; (4) Agree; (5) Strongly agree. }\end{array}$ & 0.76 & 0.81 & \\
\hline $\begin{array}{l}\text { 3. "I am sure that the cultural values and local wisdom of our country is one of the } \\
\text { best in the world" (1) Strongly disagree; (2) Disagree; (3) Uncertain; (4) Agree; (5) } \\
\text { Strongly agree. }\end{array}$ & 0.76 & 0.84 & \\
\hline $\begin{array}{l}\text { 4. "I don't like any other country to claim our authentic cultural artifacts as theirs" } \\
\text { (1) Strongly disagree; (2) Disagree; (3) Uncertain; (4) Agree; (5) Strongly agree. }\end{array}$ & 0.82 & 0.71 & \\
\hline \multicolumn{4}{|l|}{ Independent Variable 3: Economic Nationalist Sentiments } \\
\hline $\begin{array}{l}\text { 1. "Government should try its best not to purchase goods and services from } \\
\text { foreign companies/countries" (1) Strongly disagree; (2) Disagree; (3) Uncertain; } \\
\text { (4) Agree; (5) Strongly agree. }\end{array}$ & 0.87 & 0.71 & \multirow{3}{*}{$\begin{array}{l}\text { - } \text { KMO-MSA = } 0.85 \\
\text { - Bartlett's Test's Approx. } \\
\text { chi-square = 2129.77; sig = } \\
\text { 0.00 } \\
\text { - Total variance explained = } \\
53.90 \% \\
\text { - } \text { Chronbach's Alpha = } 0.83\end{array}$} \\
\hline $\begin{array}{l}\text { 2. "I dislike foreigners owning/operating business in my country" (1) Strongly } \\
\text { disagree; (2) Disagree; (3) Uncertain; (4) Agree; (5) Strongly agree. }\end{array}$ & 0.81 & 0.80 & \\
\hline $\begin{array}{l}\text { 3. "Government should control the involvement of foreign business in every sector } \\
\text { of our economy" (1) Strongly disagree; (2) Disagree; (3) Uncertain; (4) Agree; (5) } \\
\text { Strongly agree. }\end{array}$ & 0.86 & 0.72 & \\
\hline
\end{tabular}




\begin{tabular}{|c|c|c|c|}
\hline & $\begin{array}{l}\text { Anti-image } \\
\text { matrix }\end{array}$ & $\begin{array}{l}\text { Component matrix's } \\
\text { factor loading }\end{array}$ & $\begin{array}{l}\text { KMO Measure of Sampling } \\
\text { Adequacy, }\end{array}$ \\
\hline $\begin{array}{l}\text { 4. "Government should protect domestic industries by creating trade barriers for } \\
\text { foreign products" (1) Strongly disagree; (2) Disagree; (3) Uncertain; (4) Agree; (5) } \\
\text { Strongly agree. }\end{array}$ & 0.87 & 0.71 & \\
\hline $\begin{array}{l}\text { 5. "I will support politician/public officials/political parties which want to reduce } \\
\text { foreign business set-up in the country" (1) Strongly disagree; (2) Disagree; (3) } \\
\text { Uncertain; (4) Agree; (5) Strongly agree. }\end{array}$ & 0.82 & 0.78 & \\
\hline $\begin{array}{l}\text { 6. "Foreign workers can be harmful because they steal working opportunities from } \\
\text { the local" (1) Strongly disagree; (2) Disagree; (3) Uncertain; (4) Agree; (5) } \\
\text { Strongly agree. }\end{array}$ & 0.90 & 0.67 & \\
\hline \multicolumn{3}{|l|}{ Independent Variable 4: Consumer Nationalist Sentiments } & \multirow{5}{*}{$\begin{array}{l}\text { - } \text { KMO-MSA = } 0.80 \\
\text { - Bartlett's Test's Approx. } \\
\text { chi-square = 1939.12; sig = } \\
0.00 \\
\text { - } \text { Total variance explained = } \\
67.83 \% \\
\text { - } \text { Chronbach's Alpha = } 0.85\end{array}$} \\
\hline $\begin{array}{l}\text { 1. "Buying national product is always the best choice" (1) Strongly disagree; (2) } \\
\text { Disagree; (3) Uncertain; (4) Agree; (5) Strongly agree. }\end{array}$ & 0.87 & 0.74 & \\
\hline $\begin{array}{l}\text { 2. "I always try my best not to buy and to use foreign products, unless they cannot } \\
\text { be avoided" (1) Strongly disagree; (2) Disagree; (3) Uncertain; (4) Agree; (5) } \\
\text { Strongly agree. }\end{array}$ & 0.75 & 0.87 & \\
\hline $\begin{array}{l}\text { 3. "I am willing to stop buying foreign products and switch to domestic ones } \\
\text { instead" (1) Strongly disagree; (2) Disagree; (3) Uncertain; (4) Agree; (5) Strongly } \\
\text { agree. }\end{array}$ & 0.84 & 0.81 & \\
\hline $\begin{array}{l}\text { 4. "I always suggest others (my relatives and friends) not to buy foreign products" } \\
\text { (1) Strongly disagree; (2) Disagree; (3) Uncertain; (4) Agree; (5) Strongly agree. }\end{array}$ & 0.76 & 0.87 & \\
\hline
\end{tabular}

\subsection{Measuring Predictors: Nationalist Sentiments}

The study set nationalist sentiments as the independent variables. There are four types of nationalist sentiments measured - consumer, economic, socio-cultural and political. The indicators were developed from the model of consumer ethnocentrism of Shimp and Sharma (1987), economic nationalism of Baugh \& Yaprak (1996), and economic nationalism of Akhter (2007), chauvinistic model of Raijman \& Hochman (2011) and Staub (1997), and reactive nationalism of Brittingham (2005), Chan \& Bridges (2006) and Erşahin (2010).

Political nationalist sentiments, measured with three 5-point likert scale statements, is defined as nationalism of the people in political aspects. Socio-cultural nationalist sentiments, measured with four 5-point likert scale statements, is defined as nationalism of the public manifests in the social and cultural life. Economic nationalist sentiments, measured by six 5-point likert scale statements, is defined as the attitudes and actions of protecting domestic products, companies, employment opportunities, industries and people from foreign businesses, products and workers. Finally, Consumer nationalist sentiments, measured by five 5-point likert scale statements, reflects the attitudes of the citizens on foreign products - whether to purchase or avoid the products. All indicators have satisfied validity and reliability requirements.

\section{Method of Analysis}

\subsection{Difference between Responses in Three Countries}

The data were analyzed using statistical methods to differentiate responses in three countries. Firstly, univariate descriptive statistics, such as percentage, mode, mean and standard deviation were used to describe the statistical profiles of each variable (Pagano, 2013: 47-101; Gravetter \& Wallnau, 2013: 37-133). To ease the analysis of frequency distribution, the 5-likert scale responses were regrouped into 3-response categories. In this sense, those who disagreed to the statement were combined with those who completely disagreed. Similarly, those who agreed to the statement were combined with those who completely agreed. Finally, to compare the responses from the three countries, the Analysis of Variance (ANOVA) tests and Post-Hoc Least-Square Difference (Post-Hoc LSD) tests (Pagano, 2013:401-444; Gravetter \& Wallnau, 2013:385-432) were used to test the the indicators.

\subsection{Relationship between Variables}

The study has used ordinary least-square (OLS) regression (Pagano, 2013:161; Gravetter \& Wallnau, 2013:561) to estimate effect of the sentiments of political, socio-cultural, economic and consumer nationalism and the control variable on the commitment to prioritise AEC. Since the study aims to test four hypotheses, there are four OLS models created and sixteen regression analyses are estimated in order to study the effects for the entire three countries as well as in each of the countries (See Table 4). The comparison of the regression estimates across the four models is intended to 
demonstrate that (i) an analysis of nationalist sentiments on the commitment to prioritise economic regional integration without consideration of the national characteristics of the countries studied could be misleading, and (ii) economic nationalist sentiments may show different effects on different countries in the Southeast Asia in relation to the commitment for economic regional integration.

\section{Results and Discussion}

\subsection{Variation of Results by Country}

The study finds that the commitment to prioritise AEC is high, but the extent of commitment varied by countries. For the three indicators of commitment, the statistical tests of ANOVA and Post-Hoc LSD indicate that the extent of commitment in Indonesia and Malaysia is significantly higher than that in Singapore; while the extent of commitment in Malaysia is significantly higher than in Indonesia (See Table 3).

Table 3: Mean and standard deviation for dependent variables

\begin{tabular}{|c|c|c|c|c|c|c|c|c|}
\hline & \multicolumn{2}{|c|}{$\begin{array}{c}\text { Indonesia } \\
(\mathrm{N}=426)\end{array}$} & \multicolumn{2}{|c|}{$\begin{array}{l}\text { Malaysia } \\
(\mathrm{N}=401)\end{array}$} & \multicolumn{2}{|c|}{$\begin{array}{c}\text { Singapore } \\
(\mathrm{N}=213)\end{array}$} & \multicolumn{2}{|c|}{$\begin{array}{c}\text { Total } \\
(\mathrm{N}=1,040)\end{array}$} \\
\hline & Mean & $\begin{array}{l}\text { Standard } \\
\text { Deviation }\end{array}$ & Mean & $\begin{array}{l}\text { Standard } \\
\text { Deviation }\end{array}$ & Mean & $\begin{array}{l}\text { Standard } \\
\text { Deviation }\end{array}$ & Mean & $\begin{array}{l}\text { Standard } \\
\text { Deviation }\end{array}$ \\
\hline \multicolumn{9}{|l|}{ I. DEPENDENT VARIABLES: Commitment to Prioritise AEC } \\
\hline $\begin{array}{l}\text { 1. When buying goods, we should give priority to goods from ASEAN rather than } \\
\text { Non-ASEAN's. } \\
\text { - Anova's F score = } 62.61 \text {; Sig. }=0.00 \text {; Meaning: Significant differences exist. } \\
\text { - Results of Post-Hoc LSD Tests: Commitment in Indonesia and Malaysia is } \\
\text { significantly higher than that in Singapore. Commitment in Malaysia is significantly } \\
\text { higher than that in Indonesia. }\end{array}$ & 3.49 & 0.86 & 3.71 & 0.85 & 2.90 & 1.02 & 3.45 & 0.94 \\
\hline $\begin{array}{l}\text { 2. Priority should be given to investment and investors from ASEAN countries than } \\
\text { to those from countries outside ASEAN. } \\
\text { - Anova's F score = 38.18; Sig.= 0.00; Meaning: Significant differences exist. } \\
\text { - Results of Post-Hoc LSD Tests: Commitment in Indonesia and Malaysia is } \\
\text { significantly higher than that in Singapore. Commitment in Malaysia is significantly } \\
\text { higher than that in Indonesia. }\end{array}$ & 3.42 & 0.91 & 3.68 & 0.87 & 3.02 & 1.02 & 3.43 & 0.95 \\
\hline $\begin{array}{l}\text { 3. Priority should be given to skilled/professional workers from ASEAN countries } \\
\text { than those from countries outside ASEAN. } \\
\text { - Anova's F score = 38.10; Sig.= 0.00; Meaning: Significant differences exist. } \\
\text { - Results of Post-Hoc LSD Tests: Commitment in Indonesia and Malaysia is } \\
\text { significantly higher than that in Singapore. Commitment in Malaysia is significantly } \\
\text { higher than that in Indonesia. }\end{array}$ & 3.56 & 0.89 & 3.70 & 0.86 & 3.06 & 1.05 & 3.51 & 0.94 \\
\hline \multicolumn{9}{|l|}{ II. INDEPENDENT VARIABLES } \\
\hline \multicolumn{9}{|l|}{ A. Political Nationalist sentiments } \\
\hline $\begin{array}{l}\text { 1. Patriotism should be one of the main objectives of education, so our children } \\
\text { believe that our country is one of the best in the world. } \\
\text { - Anova's F score = 227.65; Sig.= 0.00; Meaning: Significant differences exist. } \\
\text { - Results of Post-Hoc LSD Tests: Sentiments in Indonesia and Malaysia are } \\
\text { significantly higher than that in Singapore. No significant difference between } \\
\text { sentiments in Indonesia and Malaysia. }\end{array}$ & 4.01 & 0.97 & 3.97 & 1.02 & 2.39 & 1.10 & 3.67 & 1.20 \\
\hline $\begin{array}{l}\text { 2. I will protest if the leader of a foreign country undermines the pride of my nation or } \\
\text { country. } \\
\text { - Anova's F score = 87.94; Sig.= 0.00; Meaning: Significant differences exist. } \\
\text { - Results of Post-Hoc LSD Tests: Sentiments in Indonesia and Malaysia are } \\
\text { significantly higher than that in Singapore. Sentiments in Indonesia are } \\
\text { significantly higher than that in Malaysia. }\end{array}$ & 4.46 & 0.70 & 3.82 & 1.79 & 3.46 & 1.18 & 4.02 & 1.36 \\
\hline $\begin{array}{l}\text { 3. I will be really angry if there is/are foreign country(ies) claiming the territory of my } \\
\text { country. } \\
\text { - Anova's F score = 154.65; Sig.= 0.03; Meaning: Significant differences exist. } \\
\text { - Results of Post-Hoc LSD Tests: Sentiments in Indonesia are significantly higher } \\
\text { than that in Malaysia and Singapore. No significant difference between sentiments } \\
\text { in Malaysia and Singapore. }\end{array}$ & 4.63 & 0.63 & 3.91 & 1.00 & 3.89 & 1.15 & 4.21 & 0.97 \\
\hline \multicolumn{9}{|l|}{ B. Socio-cultural Nationalist sentiments } \\
\hline $\begin{array}{l}\text { 1. I am always proud of the beauty of my country. } \\
\text { - Anova's F score = 97.85; Sig.= 0.00; Meaning: Significant differences exist. } \\
\text { - Results of Post-Hoc LSD Tests: Sentiments in Indonesia and Malaysia are } \\
\text { significantly higher than that in Singapore. Sentiments in Indonesia are } \\
\text { significantly higher than that in Malaysia. }\end{array}$ & 4.69 & 0.59 & 4.28 & 0.83 & 3.87 & 0.86 & 4.37 & 0.81 \\
\hline
\end{tabular}




\begin{tabular}{|c|c|c|c|c|c|c|c|c|}
\hline & \multicolumn{2}{|c|}{$\begin{array}{c}\text { Indonesia } \\
(\mathrm{N}=426)\end{array}$} & \multicolumn{2}{|c|}{$\begin{array}{c}\text { Malaysia } \\
(\mathrm{N}=401)\end{array}$} & \multicolumn{2}{|c|}{$\begin{array}{c}\text { Singapore } \\
(\mathrm{N}=213)\end{array}$} & \multicolumn{2}{|c|}{$\begin{array}{c}\text { Total } \\
(\mathrm{N}=1,040)\end{array}$} \\
\hline & Mean & $\begin{array}{l}\text { Standard } \\
\text { Deviation }\end{array}$ & Mean & $\begin{array}{l}\text { Standard } \\
\text { Deviation }\end{array}$ & Mean & $\begin{array}{l}\text { Standard } \\
\text { Deviation }\end{array}$ & Mean & $\begin{array}{l}\text { Standard } \\
\text { Deviation }\end{array}$ \\
\hline $\begin{array}{l}\text { - Anova's F score = 60.91; Sig.= 0.00; Meaning: Significant differences exist. } \\
\text { - Results of Post-Hoc LSD Tests: Sentiments in Indonesia and Malaysia are } \\
\text { significantly higher than that in Singapore. No significant difference between } \\
\text { sentiments in Indonesia and Malaysia. }\end{array}$ & 4.32 & 0.79 & 4.25 & 0.85 & 3.59 & 0.98 & 4.15 & 0.90 \\
\hline $\begin{array}{l}\text { 3. I am sure that the cultural values and local wisdom of our country is one of the } \\
\text { best in the world. } \\
\text { - Anova's F score = 154.65; Sig.= 0.03; Meaning: Significant differences exist. } \\
\text { - Results of Post-Hoc LSD Tests: Sentiments in Indonesia and Malaysia are } \\
\text { significantly higher than that in Singapore. Sentiments in Indonesia are } \\
\text { significantly higher than that in Malaysia. }\end{array}$ & 4.30 & 0.74 & 4.11 & 0.94 & 3.08 & 1.04 & 3.98 & 0.99 \\
\hline $\begin{array}{l}\text { 4. I don't like any other country to claim our authentic cultural artifacts as theirs. } \\
\text { - Anova's F score = 159.68; Sig.= 0.00; Meaning: Significant differences exist. } \\
\text { - Results of Post-Hoc LSD Tests: Sentiments in Indonesia and Malaysia are } \\
\text { significantly higher than that in Singapore. Sentiments in Indonesia are } \\
\text { significantly higher than that in Malaysia. }\end{array}$ & 4.57 & 0.71 & 3.81 & 1.05 & 3.29 & 1.07 & 4.02 & 1.05 \\
\hline
\end{tabular}

C. Economic Nationalist sentiments

1. Government should try its best not to purchase goods and services from foreign companies/countries.

- Anova's F score = 107.77; Sig.= 0.00; Meaning: Significant differences exist.

- Results of Post-Hoc LSD Tests: Sentiments in Indonesia and Malaysia are significantly higher than that in Singapore. Sentiments in Indonesia are significantly higher than that in Malaysia.

2. I dislike foreigners owning/operating business in my country.

- Anova's F score = 296.63; Sig.= 0.00; Meaning: Significant differences exist.

- Results of Post-Hoc LSD Tests: Sentiments in Indonesia and Malaysia are significantly higher than that in Singapore. Sentiments in Indonesia are significantly higher than that in Malaysia.

3. Government should try to control the involvement of foreign business in every sector of our economy.

- Anova's F score = 166.66; Sig.= 0.00; Meaning: Significant differences exist.

- Results of Post-Hoc LSD Tests: Sentiments in Indonesia and Malaysia are significantly higher than that in Singapore. Sentiments in Indonesia are significantly higher than that in Malaysia.

4. Government should protect domestic industries by creating trade barriers for foreign products.

- Anova's F score = 85.89; Sig.=0.03; Meaning: Significant differences exist.

- Results of Post-Hoc LSD Tests: Sentiments in Indonesia and Malaysia are

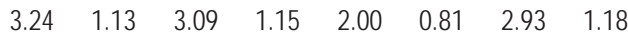
significantly higher than that in Singapore. Sentiments in Malaysia are significantly higher than that in Indonesia.

5. I will support politician/public officials/political parties which want to reduce foreign business set-up in the country.

- Anova's F score = 145.17; Sig.= 0.00; Meaning: Significant differences exist.

- Results of Post-Hoc LSD Tests: Sentiments in Indonesia and Malaysia are significantly higher than that in Singapore. Sentiments in Indonesia are significantly higher than that in Malaysia.

6. Foreign workers can be harmful because they steal working opportunities from the local.

- Anova's F score = 81.80; Sig.= 0.00; Meaning: Significant differences exist.

- Results of Post-Hoc LSD Tests: Sentiments in Indonesia and Malaysia are

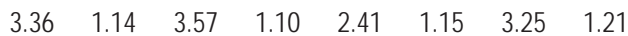
significantly higher than that in Singapore. Sentiments in Malaysia are significantly higher than that in Indonesia.

D. Consumer Nationalist sentiments

1. Buying domestic products is always the best choice.

- Anova's F score = 120.78; Sig.=0.00; Meaning: Significant differences exist.

- Results of Post-Hoc LSD Tests: Sentiments in Indonesia and Malaysia are

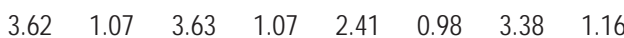
significantly higher than that in Singapore. No significant difference between sentiments in Indonesia and Malaysia.

2. I always try my best not to buy and to use foreign products, unless they cannot be avoided.

- Anova's F score = 112.70; Sig.= 0.03; Meaning: Significant differences exist.

- Results of Post-Hoc LSD Tests: Sentiments in Indonesia and Malaysia are 


\begin{tabular}{|c|c|c|c|c|c|c|c|c|}
\hline & \multicolumn{2}{|c|}{$\begin{array}{c}\text { Indonesia } \\
(\mathrm{N}=426)\end{array}$} & \multicolumn{2}{|c|}{$\begin{array}{c}\text { Malaysia } \\
(\mathrm{N}=401)\end{array}$} & \multicolumn{2}{|c|}{$\begin{array}{c}\text { Singapore } \\
(\mathrm{N}=213)\end{array}$} & \multicolumn{2}{|c|}{$\begin{array}{c}\text { Total } \\
(\mathrm{N}=1,040)\end{array}$} \\
\hline & Mean & $\begin{array}{l}\text { Standarc } \\
\text { Deviatiol }\end{array}$ & Mean & $\begin{array}{l}\text { Standard } \\
\text { Deviation }\end{array}$ & Mean & $\begin{array}{l}\text { Standard } \\
\text { Deviation }\end{array}$ & Mean & $\begin{array}{l}\text { Standard } \\
\text { Deviation } \\
\end{array}$ \\
\hline $\begin{array}{l}\text { significantly higher than that in Singapore. Sentiments in Indonesia are } \\
\text { significantly higher than that in Malaysia. }\end{array}$ & & & & & & & & \\
\hline $\begin{array}{l}\text { 3. I am willing to stop buying foreign products and switch to domestic ones instead. } \\
\text { - Anova's F score = } 76.07 \text {; Sig.= 0.00; Meaning: Significant differences exist. } \\
\text { - Results of Post-Hoc LSD Tests: Sentiments in Indonesia and Malaysia are } \\
\text { significantly higher than that in Singapore. Sentiments in Indonesia are } \\
\text { significantly higher than that in Malaysia. }\end{array}$ & 3.44 & 1.02 & 3.00 & 1.11 & 2.38 & 1.09 & 3.06 & 1.14 \\
\hline $\begin{array}{l}\text { 4. I always suggest others (my family, friends and relatives) not to buy foreign } \\
\text { products. } \\
\text { - Anova's F score = 122.33; Sig.=0.00; Meaning: Significant differences exist. } \\
\text { - Results of Post-Hoc LSD Tests: Sentiments in Indonesia and Malaysia are } \\
\text { significantly higher than that in Singapore. No significant difference between } \\
\text { sentiments in Indonesia and Malaysia. }\end{array}$ & 2.78 & 1.06 & 2.88 & 1.11 & 1.64 & 0.76 & 2.59 & 1.13 \\
\hline
\end{tabular}

In general, the extent of nationalism sentiments is higher than the extent of commitment. With regards to political nationalism, the sentiment is high in Indonesia and Malaysia. ANOVA and Post-Hoc LSD tests indicate that the extent of sentiment in Indonesia is significantly higher than that in Malaysia and Singapore. ${ }^{1}$ The details of respondents' agreements are as follow: "Patriotism should be one of the main objectives of education, so our offsprings believe that our country is one of the best in the world" (77\% Indonesians, 76 Malaysians, 20\% in Singaporeans); "I will do protest if the leader of a foreign country undermines the pride of their nation or country" (93\% Indonesians, 64\% Malaysians 59\% Singaporeans); "I will be really angry if there is/are foreign country(ies) claiming the territory of their country" (95\% Indonesians, 70\% Malaysians, 73\% Singaporeans).

Regarding socio-cultural nationalism, the sentiment is also high in Indonesia and Malaysia and slightly lower in Singapore. ANOVA and Post-Hoc LSD tests indicate that the extent of sentiment in Indonesia and Malaysia is significantly higher than in Singapore, while the sentiments in Malaysia are significantly higher than in Indonesia. Details of respondents' agreement are as follow: "I am always proud of the beauty of their country" (96\% Indonesians, 86 Malaysians, $75 \%$ Singaporeans); "I am very proud of the history and cultural heritage of their country as it forms the roots of history and culture for the Southeast Asian region" (89\% Indonesians, 84\% Malaysians, 60\% Singaporeans); "I am sure that the cultural values and local wisdom of their country is one of the best in the world" (88\% Indonesians, $79 \%$ Malaysians, 35\% Singaporeans); "I don't like any other country to claim authentic cultural artifacts of their country" (93\% Indonesians, 67\% Malaysians, 48\% Singaporeans).

As regards to economic nationalism, it still exists among public - the extent is moderate in Indonesia and Malaysia and lower in Singapore. ANOVA and Post-Hoc LSD tests indicate that the extent of sentiment in Indonesia is generally higher than that in Malaysia and Singapore. The sentiment of the Indonesians is higher than that in Malaysia and Singapore in the follow statements: "Government should try its best not to purchase goods and services from foreign companies/countries" (49\% Indonesians, 40\% Malaysians, 6\% Singaporeans); "I dislike foreigners owning/operating business in my country" (73\% Indonesians, $64 \%$ Malaysians, 4\% Singaporeans); "Government should try to control the involvement of foreign business in every sector of our economy" (86\% Indonesians, $75 \%$ Malaysians, 33\% Singaporeans); and "I will support politician/public officials/political parties which want to reduce foreign business set-up in the country" (58\% Indonesians, 52\% Malaysians, 9\% Singaporeans). However, the sentiment in Malaysia is generally higher in the two following statements: "Government should protect domestic industries by creating trade barriers for foreign products" (48\% Indonesians, 58\% Malaysians, 16\% Singaporeans); and "Foreign workers can be harmful because they steal working opportunities from the local" (51\% Indonesians, 59\% Malaysians, 19\% Singaporeans).

Finally, the consumer nationalism still exists in the public. The sentiment is moderate in Indonesia and Malaysia and much lower in Singapore. The ANOVA and Post-Hoc LSD tests indicate that the extent of sentiment in Indonesia and Malaysia is generally higher than that in Singapore. The details of sentiments are as follow: "Buying domestic products is always the best choice" (61\% Indonesians, 62\% Malaysians, 17\% Singaporeans); "I always try their best not to buy and to use foreign products, unless it cannot be avoided" (41\% Indonesians, 37\% Malaysians, $6 \%$ Singaporeans); "I am

${ }^{1}$ Because of the limit of space, details of results of ANOVA and Post-hoc LSD Test for nationalist sentiments for each indicator are not shown here. However, the results of such tests are conveyed in the study of Benny, Rashila and Tham (2014). For detailed table on this indicator, please contact the authors. 
willing to stop buying foreign products and switch to domestic ones instead" (53\% Indonesians, 34\% Malaysians, 19\% Singaporeans); and I always suggest others (my family, friends and relatives) not to buy foreign products (29\% Indonesians, 31\% Malaysians, 2\% Singaporeans).

\subsection{Comparison of Results of Economic Nationalism and Commitment}

Comparison of means between supports for AEC and economic nationalist sentiments reveals interesting finding that, in general, the level of supports is much higher than the level of nationalist sentiments in three countries. Firstly, mean values of support for AEC - 3.97 in Indonesia, 3.99 in Malaysia, and 3.80 in Singapore - are higher than the means of nationalist sentiments in three countries. Secondly, means of support for free flow of goods and services -3.54 in Indonesia, 3.97 in Malaysia and 3.94 in Singapore - are higher than the means of nationalist sentiments against foreign products. Thirdly, means of support for free movement of skilled/professional workers - 3.84 in Indonesia, 3.83 in Malaysia and 3.70 in Singapore - are higher than the means of nationalist sentiments against foreign workers. Finally, means of supports for free investment - 3.30 in Indonesia, 3.72 in Malaysia and 3.69 in Singapore - also are generally higher than the means of nationalist sentiments against foreign investment.

\subsection{Effect of Nationalist Sentiments on Commitment}

With regards to the first hypothesis, Model 1 in Table 4 shows the estimate of OLS regression for the influence of nationalist sentiments on commitment to prioritise AEC for the three countries. The model shows that sociocultural, economic and consumer nationalism is the variables that related with the commitment to prioritise AEC. The study finds no effect of political nationalism on the commitment. However, further analyses on each countries show different results. In Indonesia, political and consumer nationalism are the two variables that positively have effect on the commitment. In Malaysia, political, sociocultural, and consumer nationalism shows their effect on the commitment. In Singapore, only consumer and economic nationalism influence the commitment. Finally, it can be concluded that, based on the results in three countries, only consumer nationalism that consistently have significant effect on the commitment to prioritise AEC.

Table 4: Regression estimates for effect of nationalist sentiments on commitment for AEC

\begin{tabular}{|c|c|c|c|c|c|c|c|c|}
\hline \multirow{2}{*}{ Predictor and control variables } & \multicolumn{2}{|c|}{ Indonesia } & \multicolumn{2}{|c|}{ Malaysia } & \multicolumn{2}{|c|}{ Singapore } & \multicolumn{2}{|c|}{ Three countries } \\
\hline & B & $\sigma_{e}$ & B & $\sigma_{\mathrm{e}}$ & B & $\sigma_{\mathrm{e}}$ & B & $\sigma_{\mathrm{e}}$ \\
\hline \multicolumn{9}{|c|}{ MODEL 1: Effect of Nationalist Sentiments on the Commitment to Prioritise the AEC } \\
\hline & & & & & & & & \\
\hline Political nationalism & $0.140^{*}$ & 0.081 & $0.159^{\text {t*tok }}$ & 0.048 & -0.055 & 0.085 & 0.046 & 0.037 \\
\hline Socio-cultural nationalism & 0.037 & 0.071 & $0.126^{* * k}$ & 0.048 & 0.131 & 0.088 & $0.083^{\text {k*k }}$ & 0.037 \\
\hline Economic nationalism & -0.005 & 0.067 & 0.066 & 0.065 & $0.284^{* *}$ & 0.120 & $0.142^{k+k+k}$ & 0.041 \\
\hline Consumer nationalism & $0.252^{\text {k*kt }}$ & 0.057 & $0.112^{* k}$ & 0.054 & $0.298^{* *}$ & 0.117 & $0.208^{* k+k}$ & 0.038 \\
\hline Working experience & -0.002 & 0.085 & 0.030 & 0.083 & 0.108 & 0.152 & -0.005 & 0.056 \\
\hline R/Adjusted R square & \multicolumn{2}{|c|}{$0.305 / 0.082$} & \multicolumn{2}{|c|}{$0.389 / 0.141$} & \multicolumn{2}{|c|}{$0.361 / 0.110$} & \multicolumn{2}{|c|}{$0.405 / 0.161$} \\
\hline $\mathrm{F}$ & \multicolumn{2}{|c|}{$8.813^{\text {t*ktk}}$} & \multicolumn{2}{|c|}{$14.475^{* * *+}$} & \multicolumn{2}{|c|}{$6.339^{*+k+k}$} & \multicolumn{2}{|c|}{$41.626^{\text {thtot }}$} \\
\hline DF: regression/residual & \multicolumn{2}{|c|}{$5 / 430$} & \multicolumn{2}{|c|}{$5 / 407$} & 5 & 1211 & \multicolumn{2}{|c|}{$5 / 1061$} \\
\hline \multicolumn{9}{|c|}{ MODEL 2: Effect of Nationalist Sentiments on the Commitment to prioritise buying goods from ASEAN countries } \\
\hline Political nationalism & 0.109 & 0.075 & $0.138^{* k+k t}$ & 0.046 & -0.021 & 0.081 & 0.044 & 0.035 \\
\hline Socio-cultural nationalism & 0.033 & 0.066 & $0.094^{* *}$ & 0.046 & 0.069 & 0.084 & $0.059^{*}$ & 0.035 \\
\hline Economic nationalism & -0.028 & 0.062 & -0.003 & 0.062 & $0.283^{* *}$ & 0.114 & $0.113^{k+k+k}$ & 0.039 \\
\hline Consumer nationalism & $0.262^{* k+k x}$ & 0.052 & $0.147^{\text {*k+kt }}$ & 0.052 & $0.236^{* t}$ & 0.111 & $0.219^{* k+k}$ & 0.036 \\
\hline Working experience & -0.017 & 0.078 & 0.031 & 0.080 & 0.125 & 0.144 & -0.001 & 0.053 \\
\hline R/Adjusted R square & \multicolumn{2}{|c|}{$0.310 / 0.086$} & \multicolumn{2}{|c|}{$0.345 / 0.108$} & \multicolumn{2}{|c|}{$0.331 / 0.088$} & \multicolumn{2}{|c|}{$0.395 / 0.153$} \\
\hline $\mathrm{F}$ & \multicolumn{2}{|c|}{$9.202^{*+* k+k}$} & \multicolumn{2}{|c|}{$11.016^{\text {t*t+k}}$} & \multicolumn{2}{|c|}{$5.180^{* k+k}$} & \multicolumn{2}{|c|}{$39.374^{* k+k}$} \\
\hline DF: regression/residual & \multicolumn{2}{|c|}{$5 / 432$} & \multicolumn{2}{|c|}{$5 / 408$} & 5 & $/ 211$ & \multicolumn{2}{|c|}{$5 / 1064$} \\
\hline \multicolumn{9}{|c|}{ MODEL 3: Effect of Nationalist Sentiments on the Commitment to prioritise skilled/professional workers from ASEAN countries } \\
\hline Political nationalism & 0.088 & 0.080 & $0.092^{* *}$ & 0.046 & -0.037 & 0.080 & 0.007 & 0.036 \\
\hline Socio-cultural nationalism & 0.077 & 0.071 & $0.138^{* * k+k}$ & 0.047 & $0.140^{*}$ & 0.083 & $0.096^{\text {t*k }}$ & 0.036 \\
\hline Economic nationalism & 0.022 & 0.066 & $0.115^{\star}$ & 0.063 & $0.236^{\text {t* }}$ & 0.111 & $0.129^{t+k+k}$ & 0.040 \\
\hline Consumer nationalism & $0.201^{\star \star *+k}$ & 0.056 & 0.059 & 0.052 & $0.252^{* *}$ & 0.110 & $0.155^{\star * k+k}$ & 0.037 \\
\hline Working experience & 0.022 & 0.083 & 0.037 & 0.081 & 0.032 & 0.142 & -0.018 & 0.054 \\
\hline R/Adjusted R square & 0.270 & & 0.3521 & .113 & 0.347 & & 0.349 & 118 \\
\hline $\mathrm{F}$ & 6.7 & & 11.48 & & 5.8 & & 29.4 & \\
\hline DF: regression/residual & 51 & & $5 / 4$ & & 5 & 1211 & $5 / 1$ & \\
\hline
\end{tabular}




\begin{tabular}{|c|c|c|c|c|c|c|c|c|}
\hline \multirow{2}{*}{ Predictor and control variables } & \multicolumn{2}{|c|}{ Indonesia } & \multicolumn{2}{|c|}{ Malaysia } & \multicolumn{2}{|c|}{ Singapore } & \multicolumn{2}{|c|}{ Three countries } \\
\hline & B & $\sigma_{e}$ & B & $\sigma_{\mathrm{e}}$ & B & $\sigma_{e}$ & B & $\sigma_{\mathrm{e}}$ \\
\hline \multicolumn{9}{|c|}{ MODEL 4: Effect of Nationalist Sentiments on the Commitment to prioritise investors from ASEAN countries } \\
\hline Political nationalism & $0.153^{\star}$ & 0.081 & $0.170^{\text {*k*k }}$ & 0.046 & -0.100 & 0.083 & 0.059 & 0.036 \\
\hline Socio-cultural nationalism & -0.019 & 0.071 & $0.082^{*}$ & 0.047 & 0.125 & 0.087 & 0.050 & 0.036 \\
\hline Economic nationalism & -0.003 & 0.067 & 0.053 & 0.063 & $0.238^{* *}$ & 0.116 & $0.121^{\text {k*ktk }}$ & 0.040 \\
\hline Consumer nationalism & $0.167^{\star k+k}$ & 0.056 & 0.075 & 0.052 & $0.267^{* k}$ & 0.115 & $0.150^{* k+k}$ & 0.037 \\
\hline Working experience & 0.001 & 0.084 & 0.007 & 0.081 & 0.159 & 0.149 & 0.017 & 0.054 \\
\hline R/Adjusted R square & \multicolumn{2}{|c|}{$0.225 / 0.039$} & \multicolumn{2}{|c|}{$0.344 / 0.108$} & \multicolumn{2}{|c|}{$0.321 / 0.082$} & \multicolumn{2}{|c|}{$0.338 / 0.111$} \\
\hline $\mathrm{F}$ & \multicolumn{2}{|c|}{$4.576^{* k * k}$} & \multicolumn{2}{|c|}{$10.956^{* k+k}$} & \multicolumn{2}{|c|}{$4.873^{*+k+k}$} & \multicolumn{2}{|c|}{$27.343^{\text {tktk }}$} \\
\hline DF: regression/residual & \multicolumn{2}{|c|}{$5 / 430$} & \multicolumn{2}{|c|}{$5 / 407$} & 5 & $/ 212$ & \multicolumn{2}{|c|}{$5 / 1063$} \\
\hline
\end{tabular}

Notes: ${ }^{*} p<.1 ;{ }^{* *} p<.05 ;{ }^{* * *} p<.01 ;{ }^{* * * *} p<.005$.

The OLS multiple regression test for the second hypothesis, shown in Model 2 of Table 4, demonstrates that sociocultural, economic, and consumer nationalism significantly influence the commitment to prioritise ASEAN products and services. Thus, the study finds no effect of political nationalism on the commitment. Further analyses on each country, however, show different results. In Indonesia, consumer nationalism is the only variable that positively influences the commitment. In Malaysia, political, sociocultural, and consumer nationalism shows their positive effect on the commitment. In Singapore, consumer and economic nationalism influence the commitment. Finally, it is concluded that, based on the results in three countries, consumer nationalism is the only variable that consistently influence the commitment to prioritise ASEAN products and services.

Regarding third hypothesis, the regression estimate of model 3 in Table 4 shows the influence of sociocultural, economic and consumer nationalism on the commitment to prioritise skilled/professional workers from ASEAN countries to those from outside the region. However, there is no influence of political nationalism on the commitment. Subsequent analysis on each country indicates different findings. In Indonesia, only consumer nationalism that significantly influence the commitment. In Malaysia, there are three nationalism - political, sociocultural, and economic - that positively have impact on the commitment. In Singapore, sociocultural, economic and consumer nationalism are the three variables that positively influence the commitment. If the result in the three countries are compared, it can be concluded that none of the four types of nationalist sentiments consistently influence the commitment to prioritise ASEAN skilled/professional workers.

Model 4 in Table 4 show the result of the fourth hypothesis and demonstrates that only economic and consumer nationalism influence the commitment to prioritise investment from ASEAN businesspeople. Further analyses on each country, however, show different results - the variables that have impact on the commitments are political and consumer nationalism in Indonesia, political and consumer nationalism in Malaysia, and economic as well as consumer nationalism in Singapore. The study thus finds none of the four types of nationalism consistently shows its effect on the commitment to prioritise investment from ASEAN origin in the three countries.

Finally, it is noted that the study find unexpected result about the positive association between nationalism sentiments and commitment to prioritise AEC and its three features, as it initially predict that the effects would be negative. However, further analyses on the commitment for AEC that is higher than economic nationalist sentiments shows the reason for this anomaly - i.e. public optimism that the products, workers and business from their countries will benefit from the implementation of AEC. In this sense, they are optimistic that economic entity from their nations will win the competition and they believe that tighter competition from other ASEAN countries may leverage national business, workers, and products to upgrade the competitive advantage of their business entities.

\section{Conclusion}

The study makes important contributions to public opinion literature about Southeast Asian regionalism. Firstly, the study reveals the consistently significant effect of consumer nationalism on commitment to prioritise AEC and ASEAN products in Indonesia, Malaysia and Singapore - however, political, sociocultural and economic nationalism may have impacts differently in each country. Secondly, there is no nationalist sentiment that consistently influences the commitment to prioritise ASEAN workers and investment in the three countries, but analyses in each country randomly show positive effect of some of the four types of nationalist sentiments. Finally, the study finds that the effects of nationalist sentiments are positive and it shows the optimistic attitudes among the respondents for the benefits of AEC to the business and workers in their countries.

These findings have some implication for Southeast Asian regionalism. Even though it is found that the effects of economic nationalist sentiments are weaker if compared to European studies, economic nationalism has still 
demonstrated its negative effects on the free flow of investment and free movement features in AEC. These two features are, in fact, the key characteristics of Southeast Asian regional economic integration. Thus, the study argues that public economic nationalist sentiments should be taken into consideration in the policies for establishing regional integration in developing countries.

One limitation of the current study entails the measurement of supports that is considered to direct and simplistic. Thus, future work should seek replication of the association of the two variables studied with more varied indicators. In addition, future work can also be conducted by studying the effect of economic nationalist sentiments on other variables of attitude towards regional economic integration.

The second limitation of the study lies in limited scope of three countries from the ten countries of ASEAN. In addition, the survey only covered the original member of ASEAN and not the newer members (Brunei Darussalam, Cambodia, Laos, Myanmar and Vietnam). Thus, future research in ASEAN should involve the other countries of ASEAN, especially the newer members. Future work should seek replication of these dynamics in other developing countries where regional integration initiatives are constructed.

The third limitation is the use of convenience quota, non-random sampling to select the targeted public in the three cities. The choice of the targeted public - only those with tertiary education background - was required because of the complexity of the study questions and the limitation of resources. Therefore, the findings from the study cannot be generalized to the general public in the three countries. However, due to the large number of respondents involved, the results can be used to understand possible trends among the educated public on the issues studied.

\section{References}

Abdullah, K, \& Benny, G. (2013). Regional public opinion towards the formation of political security community in Southeast Asia. Asian Journal of Scientific Research 6(4), 650-665.

Abdullah, K, Benny, G. \& Din, M. A. O. (2010). The understanding of the idealization and conceptualization of ASEAN Community: Comparative study between Malaysia and Indonesia," Tamkang Journal of International Affairs 14(2), 91-129.

Abidin, M. Z., Mooi, L. G. \& Aziz, N. I. A. (2012). Achieving the AEC 2012: Challenges for the Malaysian Private Sector. In S. B. Das (ed.), Achieving the ASEAN Economic Community 2015 (pp.196 - 223). Singapore: Institute of Southeast Asian Studies.

Acharya, A. (2003). Democratisation and the prospects for participatory regionalism in Southeast Asia. Third World Quarterly 24(2), 375390.

Akhter, S. H. (2007). Globalization, Expectations Model of Economic Nationalism and Consumer Behavior. Journal of Consumer Marketing 24(3): 142-50.

American Association for Public Opinion Research. (2006). Standard Definitions: Final Dispositions of Case Codes and Outcome Rates for Surveys. 4th ed. Lenexa, KS: AAPOR.

ASEAN Secretariat. (1997). ASEAN Vision 2020. Jakarta: ASEAN Secretariat.

ASEAN Secretariat. (2003). Declaration of Bali Concord II. Jakarta: ASEAN Secretariat.

ASEAN Secretariat. (2009). ASEAN Economic Community Blueprint, ASEAN Secretariat, Jakarta.

Baugh, C. C. and Yaprak, A. (1996). Economic nationalism: conceptual and empirical development, Political Psychology 17(4), $759-78$.

Benny, G., Rashila, R. \& Tham, S.Y. (2014). Nationalist Sentiments and Perceived Threats: Public Opinion in Indonesia, Malaysia and Singapore and Implications to the Establishment of ASEAN Community." Tamkang Journal of International Affairs XVIII(I), 59108.

Benny, G. \& Abdullah, K. (2011). Indonesian perceptions and attitudes toward the ASEAN Community." Journal of Current Southeast Asian Affairs 30(1), 39-67.

Brittingham, M. A. (2005). Reactive nationalism and its prospects for conflict: The Taiwan issue, Sino-US relations, and the role of nationalism in Chinese foreign policy. A dissertation in the Faculty of Arts and Sciences - University of Pittsburgh.

Chan, C. P. and Bridges, B. (2006). China, Japan, and the clash of nationalisms. Asian Perspective 30(1), 127-156.

Christensen, L. B., Johnson, R. B. \& Turner, L. A. 2011. Research Methods, Design, and Analysis, 11th edn. Boston: Allyn \& Bacon.

Christin, T., \& Trechsel, A. H. (2002). Joining the EU: Explaining public opinion in Switzerland? European Union Politics 3(4), 415-43.

Das, S. B. (2012). Achieving the ASEAN Economic Community 2015: Challenges for member countries \& businesses. Singapore: Institute of Southeast Asian Studies.

Erşahin, D. (2010). An emergent form of reactive nationalism in Turkey: TürkSolu. A thesis to the Graduate School of Social Sciences of Middle East Technical University.

Dowley, K. M., \& Silver, B. D. (2011). Support for Europe among Europe's Ethnic, Religious, and Immigrant Minorities. International Journal of Public Opinion Research 23(3):315-337.

Duchesne, S. \& Frognier, A. P. (1995). Is there a European identity? In O. Niedermayer \& R. Sinnott (eds.), Public Opinion and Internationalized Governance. Oxford: Oxford University Press.

Gravetter, F. J., \& Wallnau, L. B. (2013). Statistics for the Behavioral Sciences, Ninth Edition. Wadsworth: Cengage Learning.

Guerrero, R. B. (2008). Regional integration: the ASEAN Vision in 2020. IFC Bulletin 32, 52-58.

Halliday, F. (1997) Nationalism. in J. Baylis, and S. Smith (eds.) The globalization of world politics: An introduction to International 
Relations. Oxford: Oxford University Press.

Hew, D. (2007). Brick by brick: The building of an ASEAN Economic Community. Singapore: Institute of Southeast Asian Studies.

Hooghe, L. \& Marks, G. (2004). Does identity or economic rationality drive public opinion on European integration? Political Science \& Politics 37(3), 415-20.

Hooghe, L. \& Marks, G. (2005). Calculation, community and cues: Public opinion on European integration. European Union Politics 6(4), 419-43.

Kher, P. (2012). Political economy of regional integration in South Asia. UNCTAD Background Paper No. RVC5, Geneva: UNCTAD.

Kwon, H. Y. (2010). Globalization, Cultural Openness, and Public Preferences for East Asian Economic Integration in South Korea. International Journal of Public Opinion Research 23(1), 2-23.

McLaren, L. (2007). Explaining mass-level euroscepticism: Identity, interests, and instrumental distrust. Acta Politica, 42, 233-251.

Moorthy, R. \& Benny, G. (2012a). Attitude towards community building in Association of Southeast Asian Nations: a public opinion survey. American Journal of Applied Science 9, 557-562.

Moorthy, R. \& Benny, G. (2012b). Is 'ASEAN Community' achievable? a public perception analysis in Indonesia, Malaysia and Singapore on the perceived obstacles for a regional community. Asian Survey 52(6), 1043-66.

Moorthy, R. \& Benny, G. (2013). Does public opinion count? Knowledge and support for an ASEAN Community in Indonesia, Malaysia, and Singapore. International Relations of the Asia-Pacific 13(3), 399-423.

Mugijayani, W. \& Kartika, P. (2012). Perspective of the Indonesian Business Sector on the Regional Integration Process. In S. B. Das (ed.), Achieving the ASEAN Economic Community 2015 (pp.196 - 223). Singapore: Institute of Southeast Asian Studies.

Nischalke, T. I. (2000). Insights from ASEAN's foreign policy co-operation: The 'ASEAN Way', a real spirit or a phantom? Contemporary Southeast Asia 22(1), 89-112.

Pagano, R. R. (2013). Understanding Statistics in the Behavioral Sciences, Tenth Edition. Wadsworth: Cengage Learning.

Raijman, R. \& Hochman, O. (2011). National attachments, economic competition, and social exclusion of non-ethnic migrants in Israel: A mixed-methods approach. Quality and Quantity 45, 1151-1174.

Shimp, T. \& Sharma, S. (1987). Consumer Ethnocentrism: Construction and Validation of the CETSCALE. Journal of Marketing Research 24(3): 280-9.

Shore, C. (1993). Inventing the people's Europe: Critical approaches to European Community Cultural Policy. Man 28(4), 779-800.

Smith, A. (1992). National Identity and the Idea of European Unity. International Affairs 68(1), 55-76.

Smith, A. (1993). A Europe of Nations or the Nation of Europe? Journal of Peace Research 30(2),129-35.

Staub, E. (1997). Blind versus constructive patriotism: Moving from embeddedness in the group to critical loyalty and action. In D. BartTal \& E.Staub (eds.), Patriotism in the lives of individuals and nations. Chicago: Nelson-Hall Publishers.

Tham, S. Y. (2008). ASEAN Economic Cooperation: Moving towards an ASEAN Economic Community. In S. Y. Tham, P. P. Lee \& N. Othman (eds.) Community in ASEAN: Ideas and Practices. Bangi: Penerbit University Kebangsaan Malaysia.

Thompson, E. C. \& Thianthai, C. (2008). Attitudes and Awareness toward ASEAN: Summary of Findings from a Ten Nation Survey. Jakarta: The ASEAN Foundation. 